\title{
On the three major recycling pathways in terrestrial ecosystems
}

\author{
Juli G. Pausas $\oplus^{1, *, @ a n d ~ W i l l i a m ~ J . ~ B o n d ~}{ }^{2,3}$
}

Plants are the largest biomass component of most terrestrial ecosystems, and litter decomposition is considered the dominant process by which nutrients return to plants. We show that in terrestrial ecosystems, there are three major pathways by which plant biomass is degraded into forms that release nutrients again available to plants: microbial decomposition; vertebrate herbivory; and wildfires. These processes act at different spatial and temporal scales, have different niches, and generates different ecological and evolutionary feedbacks. This holistic view in which microbes, herbivores, and wildfires play a joint role in the functioning of ecosystems contributes to a better understanding of the diversity of mechanisms regulating the biosphere.

\section{Plant Biomass}

Plants dominate the Earth, at least in terms of biomass [1], and to keep this dominance plants continually absorb nutrients from the soil and $\mathrm{CO}_{2}$ from the atmosphere. However, soils remain fertile and the atmosphere is not depleted of $\mathrm{CO}_{2}$. This is because plant biomass is also continually degradedthroughthemineralisation of organicmatter into inorganic compounds available again to plants (terrestrial carbon and nutrient cycling). Litter decomposition has been considered the dominant process generating this degradation[2]. Here, wearguethat in terrestrial ecosystems, therearethree major pathways by which theorganicmatter and nutrients in the plant biomass are made again available to plants: microbial decomposition; vertebrate herbivory; and wildfires(Figure1). Each ofthesethreeprocesseshasdifferentrequirementsandactsatdifferent spatial and temporal scales (Table 1). The three processes have been described independently elsewhere, and recent studies have linked fire with decomposition [3] or herbivory [4], with emphasis on leaf traits (flammability, decomposability, and palatability). Here, weaimto widen theseviews and suggesta unified frameworkthatintegratesthethreemajor recycling pathways that drive the structure and biogeochemistry of terrestrial ecosystems (Figure 1), considering feedbacks and evolutionary implications.

Microbes, Herbivores, and Wildfires

Microbial decomposition (including decay fungi that may produce macroscopic structures) is a slow and efficient soil process that transforms organic matter into $\mathrm{CO}_{2}$ and makes nutrients again available for plants. This process acts on dead above- and below-ground biomass (litter androots), andmostnutrients are returnedtothesoilneartheoriginal plant(local scale process). It is a well-known process, dominant in forest and moist environments, and has been reviewed elsewhere [2,5-7] including in major ecology textbooks. On an evolutionary timescale, microbial decomposition likely peaked in the Eocene, when the climate was warmand relatively wet, and forests were dominant (dinosaurs werealreadyextinctand mammals werestill small). Microbial decomposition isalso promoted bytermites, earthworms, and other invertebrates $[8,9]$ without changing the spatial scale of the process and the type of biomass decomposed. Thus, theinvertebrate contribution to decomposition is included as part of the microbial cycles.
${ }^{1}$ Centro de Investigaciones sobre Desertificación (CIDE-CSIC), Valencia, Spain

${ }^{2}$ Department of Biological Sciences, University of Cape Town, Cape Town, South Africa

${ }^{3}$ South African Environmental Observation Network, National Research Foundation, Claremont, South Africa

*Correspondence:

juli.g.pausas@ext.uv.es,

juli.g.pausas@csic.es (J.G. Pausas).

${ }^{\circledR}$ Twitter: @jgpausas (J.G. Pausas). 


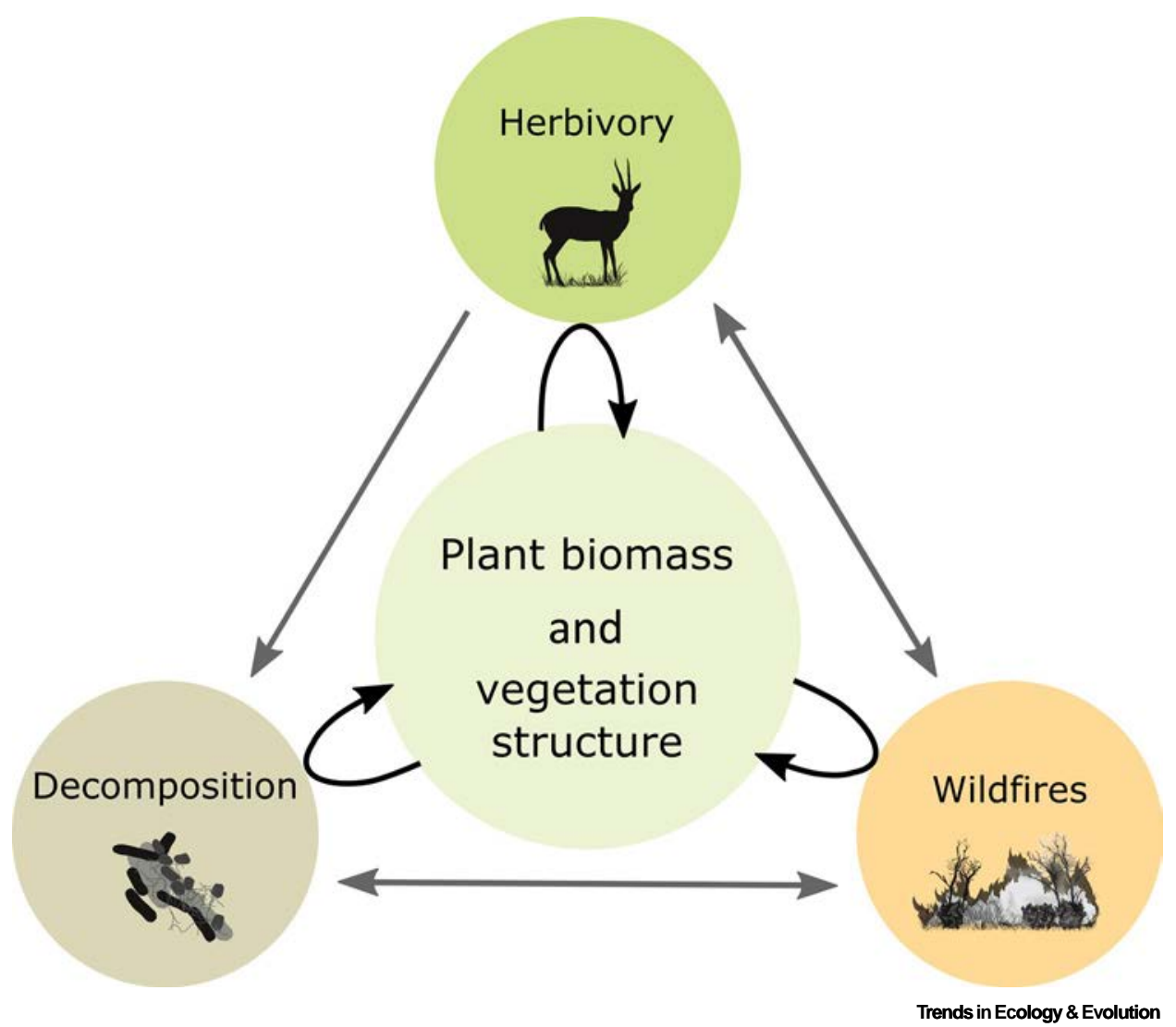

Figure1. PlantBiomassand VegetationStructureinTerrestrial Ecosystemsis Determined byThreeFeedback Processes: Vertebrate Herbivory, Microbial Decomposition, and Wildfires. These three processes also interact with each other (thin straight lines). All these interactions are negative (competition for biomass), but positive interactions also exist. Illustration by Dharmaberen Studio (www. dharmaberen.com).

Herbivorybyvertebratesalso makesamajorcontributiontoregulating plantbiomassand carbon and nutrient cycling $[10,11]$. Unlike soil microbial decomposition, vertebrate herbivory acts primarily on aboveground green biomass, and theCemission is often inthe form of methane, especiallybyruminants. Vertebrateherbivoresarehighlymobile plantconsumers, and byharbouring microbes in their guts (i.e., rumen-associated Archaea), they spatially distribute organic matter and nutrients across the landscape [12,13]. In the case of migratory herbivores, the spatial scale of the redistribution can be large $\left(10^{2}-10^{4} \mathrm{~m}\right)$. Herbivory is an old ecological process $[14,15]$ and there have been significant numbers of large herbivores at least since the Middle J urassic (180Ma) and the Cretaceous (145-66 Ma; whenthelargest ever terrestrial herbivores, the sauropods, roamed the planet [16]).

Thethird process is wildfire [17-19]. Fires can consumeany aboveground plant biomass ( green and dead), and transformitinto formsavailableto plants. This pyromineralisation is directly produced by ash inputs or through heat (thermal mineralisation [18]). Some of these breakdown productsremain at thesiteornearby (ashes), including veryrecalcitrant (poorlydecomposable) forms that act as soil Csink (pyrogenic C [20]), while other forms move far from the site during the fire (via smoke), or afterwards with rain (runoff). Consequently, wildfires can redistribute nutrients on very large spatial scales (Table 1), making great contribution to global biogeochemical cycles. For instance, African savannas supply nutrients to adjacent forests [21,22] but they can 
Table 1. Main Characteristics of Three Major Routes for Breaking-Down of Organic Matter into Simple I norganic Compounds and Nutrients. These characteristics definetheniche of each process.

\begin{tabular}{|c|c|c|c|}
\hline & Vertebrate herbivory & Microbial decomposition & Wildfires \\
\hline \multicolumn{4}{|l|}{ Conditions } \\
\hline Climate optima & Dry, temperate & Moist & With a dry season \\
\hline Soil preferences & Nutrient rich & Moist & Nutrient poor \\
\hline Vegetation types & Open & Closed & Open \\
\hline \multicolumn{4}{|l|}{ Requirements } \\
\hline Type ofbiomass & Aboveground plant & $\begin{array}{l}\text { Aboveand belowground plant; } \\
\text { animal }\end{array}$ & Aboveground plant \\
\hline Plant biomass consumed & Green and fleshy & Dead (litter, roots) & Dead and green \\
\hline Relevant plantattributes & Leaf quality (palatability) & Litter quality & Biomass structure, flammability \\
\hline Biomass $\mathrm{C} / \mathrm{N}$, Lignin/N & Low & Low & High \\
\hline Biomass continuity & Temporal continuity & Contact with soil & Spatial continuity \\
\hline Additional requirement & Water & Defaunation & Ignitions \\
\hline \multicolumn{4}{|l|}{$\mathrm{C}$ and nutrient cycling } \\
\hline $\mathrm{CO}_{2}$ emission & Low & High & High \\
\hline Methane emission & High & Low (e.g., termites) & Low (e.g., peat fires) \\
\hline Recycling rate & Intermediate/fast & Slow & Fast, episodic \\
\hline Spatial scale (m) & $10^{2}-10^{4}$ & $\mathrm{~b} 10^{2}$ & $\mathrm{~N} 10^{4}$ \\
\hline $\begin{array}{l}\text { Seasonality } \\
\text { (nutrient turnover) }\end{array}$ & Low & Low & High \\
\hline \multicolumn{4}{|l|}{ Consequences } \\
\hline Vegetation feedback & Yes, palatability (grasses) & Yes, plant-soil & Yes, flammability \\
\hline For the ecosystem & Maintain open habitats & Maintain local fertility & Generate and maintain open habitats \\
\hline $\begin{array}{l}\text { Plant response traits } \\
\text { (adaptations) }\end{array}$ & $\begin{array}{c}\text { Plant structural and chemical defences, } \\
\text { trample resistance (grasses) }\end{array}$ & Decomposability & $\begin{array}{l}\text { Flammability, lignotubers, seed } \\
\text { dormancy, thick bark, etc. }\end{array}$ \\
\hline \multicolumn{4}{|l|}{ Interactions } \\
\hline Regulated by & Predators, pathogens & Moisture, temperature, soil & Topographic barriers, ignitions, humans \\
\hline Regime factors & Density, size, gut type, sociability & Climate & Intensity, frequency, size, season \\
\hline $\begin{array}{l}\text { Sensitivity to climate } \\
\text { change }\end{array}$ & Low & Intermediate & High \\
\hline \multicolumn{4}{|l|}{ History } \\
\hline Evolutionary origin (Ma) & 300 Ma (Synapsids) & $\begin{array}{c}400 \mathrm{Ma} \text { (arbuscular mycorrhiza } \\
\text { fungi) }\end{array}$ & $400 \mathrm{Ma}$ \\
\hline Peaks & Mesozoic (dinosaurs), Pleistocene (mammals) & Eocene (warm, moist, forests) & Carboniferous, Permian, Cretaceous \\
\hline Sources of variability & Ruminant, nonruminant; grazers, browsers & $\begin{array}{l}\text { Ectomycorrhiza, arbuscular } \\
\text { mycorrhiza, root diameter }\end{array}$ & Grass-, litter-, woody-fuelled \\
\hline
\end{tabular}

alsosupply up to a half of theP deposited annually in the Amazon basin [23]. Thespecific biogeochemical effect of a fire varies greatly with climate, vegetation type, postfire weather, and especially with fire characteristics (mainly intensity), but at the local scale, fires tend to increase soil cations and decrease N [19,24]. In addition, wildfires also contribute to rock weathering [25] and thusinfluencetheinput of nutrientsintoecosystems. I ncontrast to microbial decomposition and herbivory, wildfires consume biomass quickly and episodically. During the fire-freeinterval, biomass in fire-prone ecosystems builds up, as decomposition and herbivory is unable to cope with productivity. Most wildfires do not produce as much methane as herbivory [26]. Peat fires 
are an exception and may produce large amounts of methane and other organic compounds [27]. Wildfires are an ancient process ( from $\sim 420 \mathrm{Ma}$ ), older than vertebrate herbivory, appearing soon after plants colonised the land in the Silurian, and gaining importance with the increase in plant complexity and vegetation density and, especially, during the high atmospheric $\mathrm{O}_{2}$ peaks [28]. Wildfires have also been suggested as a key factor stabilising oxygen levels during the past370millionyears[29].

\section{Niche Partitioning}

All threeprocesses can occur in a given ecosystem (competing for the same resource, biomass), but the relative importance of each varies with the micro- and macro-environmental conditions (Figures 2 and 3, Table 1). For instance, wildfires are prevalent at intermediatelevels of productivity [30] where climates are seasonal ( with a period of high productivity that builds up fuels, followed by a dry period that makes those fuels flammable), and especially in poor soils [31]. They require regular ignitions and spatial continuity of vegetation [31]. Vertebrate herbivory is important in climates with low rainfall seasonality and fertile soils (to maintain animal populations, although animal migration may, to some extent, buffer someof theserequirement [32]). Herbivoreactivity is naturally modulated by predators and parasites, and currently by human activities. Microbial decomposition is dominant where wildfires are limited (e.g., too moist), or in areas with few herbivores (e.g., because of the Pleistocene defaunation); decomposition requires some moisture (which also reduces flammability), and thus this pathway dominates in many temperate forests [33]. In savannasand dryenvironments, wheresuch conditionsarescarce, microbial decomposition of the aboveground biomass may be helped by photodegradation, and especially by termites and (fungal farming) ants which digest organic matter in their guts [8].

The importance of fire and herbivory as key ecological factors has been traditionally underestimated [34]; however, the fact that inmany environments they can maintainopen ecosystems in places that can potentially support forests $[35,36]$ suggests that in those conditions, fireorherbivores routinelycausegreater loss of plantbiomassthan decomposition. Forinstance,

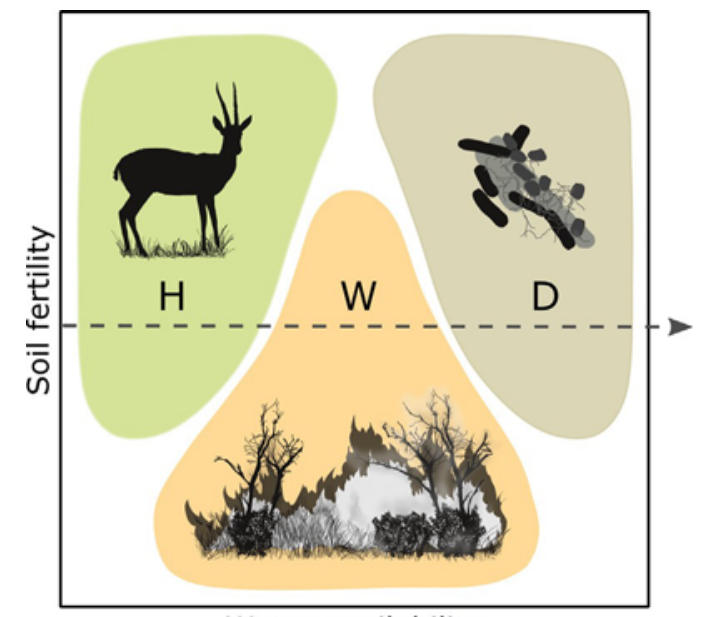

Water availability

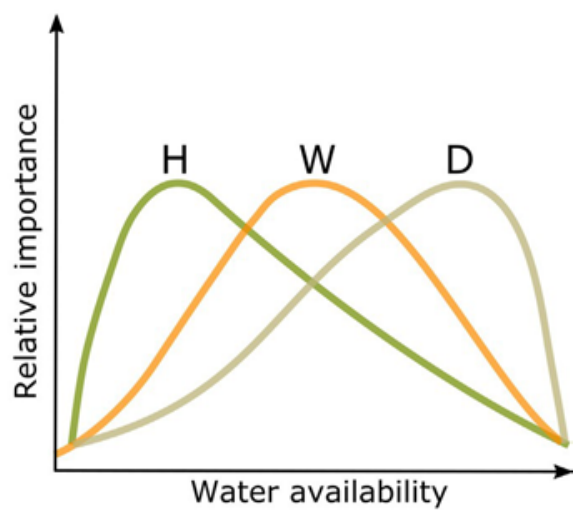

Trends in Ecology \& Evolution

Figure 2. Relative Importance of Each of the Three Ecosystem Pathways (H: Vertebrate Herbivory; W: Wildfires; D: Microbial Decomposition) in theEnvironmental Space(Niche) Defined bytheWater Availability and Soil Fertility. Note that at the intermediate levels of water availability, rainfall is typically seasonal, Illustration by Dharmaberen Studio (www.dharmaberen.com). 
Given the different requirements and conditions among thethree pathways, wecan classify the world's ecosystems following the dominant process of aboveground biomass degradation: herbivore-driven, microbe-driven, and fire-driven ecosystems. These types are linked to the brown, green, and blackworlds (respectively) proposed for describing the drivers of vegetation structure [38]. We focus on these three main processes as they should account for most of the variability in structuring communities and in biogeochemical cycles (Table 1); however, we recognise some variability within each process with some biogeochemical consequences. For instance, in herbivory-driven ecosystems, ruminants emit more methane than nonruminants do [32]; in fire-driven ecosystems, different fire regimes (e.g., surface vs. crown-fire regimes) generate contrasted patterns of biomass turnover ( $a$ nd $\mathrm{CO}_{2}$ emission) [20,31]; and in microbe-driven ecosystems, different microbe types (e.g., ectomycorrhizae, arbuscular mycorrhizae, and $\mathrm{N}_{2}$ fixing bacteria) have different niches [33].

Despitethesedifferences among thethree processes (Table1), theyalsooverlapin theenvironmental space (Figure 2). This is because the three processes partially target different biomass components(e.g., belowground biomassismostly degradedbydecompositioninanyenvironment; Table 1), butalso becausethere aresome positive interactions. For instance, wildfires generate openspacesand, in savannasandsteppes, maintain afresh grass layerfor herbivores, whilepostfire conditions (high pH, light, and temperature) temporarily increase microbial activity and mineralisation rates [39]; browsers can kill trees, fuelling microbial decomposition, but they can also maintain flammable fuel beds for fires to spread; and herbivores can promote microbial decomposition from faeces, and stimulate root exudation of carbon and microbial activity [40]. However, further work is needed to fully understand and quantify interactions between thesethreeprocesses ata global scale.

\section{Feedbacks and Evolutionary Implications}

Wildfires and herbivory are two powerful biomass consumers [32,34,36,41]; they generate feedback processes that maintain vegetation at states of lower biomass than would be expected from the physical environmental conditions (alternative vegetation states [35]). This lower biomass vegetation is moreflammableor more palatableand thusfeeds backinto maintaining the consumer. Wildfires and herbivorynotonlygeneratetheseecological feedbacksthat maintain openecosystems, but also select for light-loving species with a set of adaptive traits to persist under these consumers [36]. Thatis, plantconsumershavea clearevolutionaryrolein fire-proneand grassyenvironments. Thus, there are plant traits strongly associated with fire (e.g., thick bark, serotiny, epicormic resprouting, lignotubers, postfire flowering, and flammability [31,42-44]), and others strongly associated with herbivory (e.g., spines, toxicity, and low palatability in woody plants; basal resprouting and trampleresistanceingrasses; $[15,45])$, reflectingtheircontrasted niche. Thatis, both herbivory and fire can influencethemix and attributes of plantspecies, whilethemixand attributes of plants also influencethefireand grazing regimes. Thisfeedbackmakes fireand herbivory distinctfrom other physical disturbances such as cyclones, landslides, avalanches, volcanoes, or floods, where plants may respond - but the disturbance will not change in response to these plant responses. Although lessstudied, therearealso animal traitsassociated with fireand herbivory[46,47].

Decomposability traits are different from flammability traits, including at the leaf level $[3,48,49]$ which is where decomposition could mostly interact with fire(e.g., contrasted $\mathrm{N}$ and lignin concentration; Table 1); decompositions also acts in roots. In contrast, leaf decomposability and palatability share some similarities, as highly palatable plants are more attractive to both herbivores and microbes [50]; however, the former acts ongreen biomassand thelatter on dead biomass, and their dominance is in different environments (open vs. closed vegetation types; Table 1, Figures 2 and 3). Decomposability traits have been well studied and determine the rate of the plant-soil feedback loop 
[3,5,51,52]; that is, plantspecies composition determines litter qualityand decomposition rates (at leastforthefirststages of litterdegradation) whichfeedbacktonutrientavailabilityand plantgrowth and vegetation composition. Thus, thereis growing evidenceof microbial-mediated coexistencein plants [53]. However, the evolutionary role of changing decomposition has been little explored [54,55], and issometimesrelatedtotheevolution of novel roottraits [56].

All three pathways have also been invoked to generate feedbacks that contribute to explain Darwin's 'abominable mystery', that is, the origin and expansion of angiosperms in the Cretaceous (from gymnosperm-dominated landscapes). Bakker [57] suggested that a swift and extensive change in feeding behaviour of herbivorous dinosaurs was one key event that opened opportunitiesfortherapidinitial diversification of angiosperms. BondandScott[58] suggested that the high levels of $\mathrm{O}_{2}$ and high climate seasonality in the Cretaceous, along with fast-growing plants, generated novel fire regimes and open conditions promoting the spread of angiosperms. Berendseand Scheffer[59] suggested that thehighergrowth rateof angiosperms promoted litter that more easily decomposes and so generates a positive feedback favouring angiosperms. Our framework suggests that all these processes are not mutually exclusive as theycould havebeenoccurring intheCretaceousunderdifferentenvironments(Figure2).

Alternativevegetationstates[35] canbeviewedas shiftsbetween differentdominant pathways. For instance, in forest-savanna mosaics $[41,60,61]$ the biogeochemical cycles of forest (microbe-driven) are very different from those in savanna which can be dominated by firedriven or herbivore-driven processes [32]. The increasing understanding of the abrupt loss of megaherbivores in the late Quaternary [62] suggests not only landscapeand biodiversity shifts [63], but also a shift from herbivore-driven to microbe-driven ecosystems in many temperate landscapes [64], as well as to fire-driven ecosystems in seasonally dry landscapes such as Australia [65]. The biogeochemical consequences of these shifts have been little explored. For instance, the recent reduction in the number of hippopotamuses that feed in grasslands in the watershed of the African Great Lakes has caused changes in nutrient cycling, with strong shifts of planktonic communities of the lakes [13]. Even stronger consequences may have occurred during past massive defaunation events. In fact, it has been suggested that before the Miocene expansion of $\mathrm{C}_{4}$ grasses, silica was in short supply; afterwards, grazers accelerated the delivery of silica to water bodies, greatly facilitating diatomsuccess [66]. The Miocene expansion of grasslands over forests enhanced both herbivory and wildfire activity, with huge biogeochemical consequences; but the change in the dominant life form (grasses over trees) implied a strong reduction of the chemical weathering by plants (and of the carbonate deposition on the seafloor) that contributed to stabilize atmospheric $\mathrm{CO}_{2}$ levels [67].

Another abruptshift in the biogeochemical cycles is likely to have occurred in the Carboniferous. The evolution by plants of the ability to synthesise tough lignin increased litter accumulation, leading to an increase in the atmospheric oxygen concentrations [66,68]. Oxygen concentration could have dropped later thanks to a peak of wildfires in an oxygen-rich environment $[28,29]$, and to the evolution of enzymes to break down the lignin in decomposers [69].

\section{Concluding Remarks}

Thethree pathways occur in terrestrial ecosystems; however, the implications are not limited to those ecosystems as they affect watershed nutrient cycling by recirculating nutrients through water bodies [70] and to the ocean (losses from the land system). That is, the three pathways have and had implications for the whole Earth system [29,71,72]. Overall, we propose that the three processes provide important ecological feedbacksfor understanding theecology and evolution of our biosphere. 
Our framework opens up a global research agenda to quantify and map the relative role of each process in biochemical cycles across the world and through evolutionary history (see Outstanding Questions). Itshouldalsohelpfocusonkeyprocesseswhenmodellingthedynamics of our biosphere. The dominant paradigm of soil decomposition as the key degradative factor of biomass may bedueto the fact that it acts at small scale (thescale of most traditional research), but also, because mainstream ecology emerged in temperate environments [34] where high water availability, relatively fertile soils, and Pleistocene defaunation, makes this process the most prominent (Figure 2). However, in recent years, new technologies (such as advances in geospatial information, phylogenetic techniques, and palaeoecology) enable us to better understand herbivory and wildfires at largespatial and temporal scales, and thus ascertain their key role in maintaining thestructure, dynamics, and nutrient cycling of many extant and extinctecosystems worldwide $[13,34-36,60,61,73]$.

By setting microbial activity, herbivory, and wildfires in a unified framework, wehopeto promote bringing together ecosystem ecology and disturbance ecology. We propose that plant consumers (herbivory and fire) play (and have played) a fundamental role in the Earth's system. By reducing biomass, they not only delay competition and allow the growth of a diversity of organisms [74], but they also play a major role in biogeochemical cycles. How these cycles have changed overevolutionarytime, and how arecurrentlychanging inagloballychanging world, requires the integration of all the different recycling pathways at large spatial and temporal scales (see Outstanding Questions). By embracing a more holistic view in which microbes, herbivores, and fires playa joint rolein thefunctioning of the Earth system, ecology is contributing to a better understanding ofthenicheconstruction of life.

\section{Acknowledgements}

This research has been performed under the framework of the projects FI ROTIC (PGC2018-096569-B-I00, Spanish Government) and FOCSEC (PROMETEO/2016/021, Generalitat Valenciana). We thank J ordi Garcia-Pausas for helpful commentsonanearlydraft.

References

1. Bar-On, Y.M. et al. (2018) The biomass distribution on Earth. Proc. Natl. Acad. Sci. U. S. A. 115, 6506-6511

2. Facelli, J.M. and Pickett, S.T.A. (1991) Plant litter: its dynamics and effects on plant community structure. Bot. Rev. 57, 1-32

3. Cornelissen, J.H.C.etal. (2017) Arelitter decompositionandfire linked through plant species traits? New Phytol. 216, 653-669

4. Archibald, S. et al. (2019) A unified framework for plant life history strategies shaped by fire and herbivory. New Phytol. 224, 1490-1503

5. Coûteaux, M.M. et al. (1995) Litter decomposition, climate and litter quality. Trends Ecol. Evol. 10, 63-66

6. Bradford, M.A. et al. (2016) Understanding the dominant controls on litter decomposition. J. Ecol. 104, 229-238

7. Crowther, T.W. et al. (2019) The global soil community and its influenceonbiogeochemistry. Science 365 , eaav0550

8. Brune, A. (2014) Symbiotic digestion of lignocelluloseintermite guts. Nat. Rev. Microbiol. 12, 168-180

9. Ulyshen, M.D. (2016) Wood decomposition as influenced by invertebrates. Biol. Rev. 91, 70-85

10. Metcalfe, D.B. etal. (2014) Herbivorymakes majorcontributions to ecosystem carbon and nutrient cycling in tropical forests. Ecol. Lett. 17, 324-332

11. Berzaghi, F. etal. (2019) Carbon stocks incentral African forests enhanced by elephant disturbance. Nat. Geosci. 12, 725-729

12. Polis, G.A. et al. (1997) Toward an integration of landscapeand food web ecology: the dynamics of spatially subsidized food webs. Annu. Rev. Ecol. Syst. 28, 289-316

13. Schoelynck, J.etal. (2019) Hippos (Hippopotamus amphibius): the animal silicon pump. Sci. Adv. 5, eaav0395

14. Doughty, C.E. (2017) Herbivores increasetheglobal availability of nutrientsovermillions of years. Nat. Ecol. Evol. 1, 1820-1827
15. Charles-Dominique, T. et al. (2016) Spiny plants, mammal browsers, and the origin of African savannas. Proc. Natl. Acad. Sci. U. S. A. 113, E5572-E557

16. Brusatte, S.L. et al. (2010) The origin and early radiation of dinosaurs. Earth-Sci. Rev. 101, 68-100

17. Bowman, D.M.J.S. etal. (2009) FireintheEarth system. Science $324,481-484$

18. Hartshorn, A.S. etal. (2009) Pyromineralization of soil phosphorus in a South African savanna. Chem. Geol. 267, 24-31

19. Pellegrini, A.F.A. et al. (2018) Fire frequency drives decadal changes insoil carbonandnitrogenandecosystemproductivity. Nature 553, 194-198

20. Jones, M.W. et al. (2019) Global fire emissions buffered by the production of pyrogenic carbon. Nat. Geosci. 12, 742-747

21. Chen, Y.etal. (2010) Nitrogen deposition in tropical forestsfrom savannaanddeforestationfires. Glob. Chang. Biol. 16, 2024-2038

22. Bauters, M. etal. (2018) Highfire-derivednitrogendepositionon central African forests. Proc. Natl. Acad. Sci. U. S. A. 115, 549-554

23. Barkley, A.E. et al. (2019) African biomass burning is a substantial source of phosphorus deposition to the Amazon, Tropical Atlantic Ocean, and Southern Ocean. Proc. Natl. Acad. Sci. U. S. A. 201906091

24. Raison, R.J. et al. (1985) Mechanisms of element transfer to the atmosphere during vegetation fires. Can. J. For. Res. 15, $132-140$

25. Shakesby, R.A. and Doerr, S.H. (2006) Wildfire as a hydrological andgeomorphological agent. Earth-Sci. Rev. 74, 269-307

26. Nisbet, E.G. et al. (2019) Very strong atmospheric methane growth in the 4 years 2014-2017: Implications for the Paris agreement. Glob. Biogeochem. Cycles 33, 318-342 
27. Hu, Y.etal. (2018) Review of emissionsfromsmoulderingpeatfires and their contribution to regional hazeepisodes. Int. J. Wildland Fire 27, 293-312

28. Scott, A.C. (2018) Burning Planet: The Story of Fire through Time, Oxford University Press

29. Lenton, T.M. andWatson, A.J. (2000) Redfieldrevisited: 2. What regulates the oxygen content of the atmosphere? Glob. Biogeochem. Cycles 14, 249-268

30. Pausas, J.G. and Ribeiro, E. (2013) The global fire-productivity relationship. Glob. Ecol. Biogeogr. 22, 728-736

31. Keeley, J.E. et al. (2012) Fire in Mediterranean Ecosystems: Ecology, Evolution and Management, CambridgeUniversity Press

32. Archibald, S. and Hempson, G.P. (2016) Competing consumers: contrasting the patterns and impacts of fire and mammalian herbivory in Africa. Philos. Trans. R. Soc. B 371, 20150309

33. Steidinger, B.S. et al. (2019) Climatic controls of decomposition drive the global biogeography of forest-tree symbioses. Nature 569, 404-408

34. Pausas, J.G. and Bond, W.J. (2019) Humboldt and the reinvention of nature. J. Ecol. 107, 1031-1037

35. Pausas, J.G. and Bond, W.J . (2020) Alternative biome states in terrestrial ecosystems. Trends Plant Sci. 25, 250-263

36. Bond, W.J. (2019) Open Ecosystems: Ecology and Evolution Beyond the Forest Edge, Oxford University Press

37. Murphy, B.P. et al. (2019) Biomass consumption by surfacefires across Earth's most fire-pronecontinent. Glob. Chang. Biol. 25 254-268

38. Bond, W.J. (2005) Large parts of the world are brown or black: a different view on the "Green World" hypothesis. J. Veg. Sci. 16, 261-266

39. Stock, W.D. and Lewis, O.A.M. (1986) Soil nitrogen and therole of fire as a mineralizing agent in a South African coastal fynbos ecosystem. J. Ecol. 74, 317-328

40. Hamilton III, E.W. and Frank, D.A. (2001) Can plants stimulate soil microbes and their own nutrient supply? Evidence from a grazing tolerantgrass. Ecology 82, 2397-2402

41. Bond, W.J. (2008) What limits trees in C4 grasslands and savannas? Annu. Rev. Ecol. Evol. Syst. 39, 641-659

42. Pausas, J.G. (2015) Barkthickness andfire regime. Funct. Ecol. 29, 315-327

43. Pausas, J.G. et al. (2017) Flammability as an ecological and evolutionarydriver. J. Ecol. 105, 289-297

44. Lamont, B.B. etal. (2019) Evolutionaryhistoryoffire-stimulated resprouting, flowering, seed releaseandgermination. Biol. Rev. 94, 903-928

45. Owen-Smith, R.N. (2002) Adaptive Herbivore Ecology: From Resources to Populations in Variable Environments, Cambridge University Press

46. Provenza, F.D. etal. (1992) Mechanisms of learningin dietselection with reference to phytotoxicosis in herbivores. J. Range Manag. 45, 36-45

47. Pausas, J.G. and Parr, C.L. (2018) Towards an understanding of theevolutionaryrole of fireinanimals. Evol. Ecol. 32, 113-125

48. Grootemaat, S. et al. (2015) Burn or rot: leaf traits explain why flammabilityanddecomposabilityaredecoupledacrossspecies. Funct. Ecol. 29, 1486-1497

49. Semenova-Nelsen, T.A. et al. (2019) Frequent fire reorganizes fungal communities and slows decomposition across a heterogeneous pine savanna landscape. New Phytol. 224, 916-927

50. Cebrian, J. (1999) Patterns in the fate of production in plant communities. Am. Nat. 154, 449-468
Cornwell, W.K. et al. (2008) Plant species traits are the predominantcontrol on litterdecomposition rates withinbiomes worldwide. Ecol. Lett. 11, 1065-1071

52. Freschet, G.T. et al. (2012) A plant economics spectrum of litter decomposability. Funct. Ecol. 26, 56-65

53. Crawford, K.M. et al. (2019) When and where plant-soil feedback may promote plant coexistence: a meta-analysis. Ecol. Lett. 22, 1274-1284

54. Berendse, F. (1994) Litter decomposability - a neglected component of plant fitness. J. Ecol. 82, 187-190

55. Van Nuland, M.E. et al. (2019) Ecosystemfeedbacks contribute to geographic variation in plant-soil eco-evolutionary dynamics across afertility gradient. Funct. Ecol. 33, 95-106

56. Ma, Z etal. (2018) Evolutionaryhistoryresolvesglobalorganization of rootfunctional traits. Nature 555, 94-97

57. Bakker, R.T. (1978) Dinosaurfeeding behaviourandtheoriginof flowering plants. Nature 274, 661

58. Bond, W.J. and Scott, A.C. (2010) Fire and the spread of flowering plants in the Cretaceous. New Phytol. 188, 11371150

59. Berendse, F. and Scheffer, M. (2009) Theangiospermradiation revisited, an ecological explanation for Darwin's 'abominable mystery'. Ecol. Lett. 12, 865-872

60. Staver, A.C. et al. (2011) Theglobal extent and determinants of savanna and forest as alternative biome states. Science 334 230-232

61. Dantas, V.L. et al. (2016) Disturbance maintains alternative biomestates. Ecol. Lett. 19, 12-19

62. Dirzo, R. etal. (2014) Defaunation intheAnthropocene. Science 345, 401-406

63. Barnosky, A.D. et al. (2016) Variable impact of late-Quaternary megafaunal extinction in causing ecological state shifts in North and South America. Proc. Natl. Acad. Sci. U. S. A. 113 856-861

64. Zimov, S.A. et al. (1995) Steppe-tundra transition: a herbivoredriven biome shift at the end of the Pleistocene. Am. Nat. 146, 765-794

65. Flannery, T. (2002) The Future Eaters: An Ecological History of the Australasian Lands and People, Grove Press

66. Beerling, D.J . (2007) The Emerald Planet. How Plants Changed Earth's History, Oxford University Press

67. Pagani, M. et al. (2009) The role of terrestrial plants in limiting atmospheric $\mathrm{CO}_{2}$ decline over the past 24 million years. Nature 460, 85-88

68. Berner, R.A. and Canfield, D.E. (1989) A new model for atmospheric oxygen over Phanerozoic time. Am. J. Sci. 289, 333-361

69. Robinson, J.M. (1990) Lignin, land plants, and fungi: biological evolution affecting Phanerozoic oxygen balance. Geology 18 , 607-610

70. Richey, J.E. et al. (2002) Outgassing fromAmazonian riversand wetlands as a large tropical source of atmospheric $\mathrm{CO}_{2}$. Nature 416, 617-620

71. Kump, L.R. (1988) Terrestrial feedback in atmospheric oxygen regulation by fireand phosphorus. Nature 335, 152-154

72. Schmitz, O.J . et al. (2018) Animals and the zoogeochemistry of the carbon cycle. Science 362, eaar3213

73. van der Werf, G.R. et al. (2017) Global fire emissions estimates during 1997-2016. Earth Syst. Sci. Data 9, 697-720

74. He, T. et al. (2019) Fire as a key driver of Earth's biodiversity Biol. Rev 94, 1983-2010

51 